\title{
Upaya Meningkatkan Kemampuan Fisik Motorik Kasar Anak Melalui Kegiatan Melambungkan dan Menangkap dengan Berbagai Media Anak Usia Dini Di TK Al- Fajar Pekanbaru
}

\author{
oleh: \\ Melvi Lesmana Alim \\ Dosen Prodi PG-PAUD, STKIP Pahlawan Tuanku Tambusai
}

\begin{abstract}
Abstrak
Berdasarkan hasil observasi peneliti dikelompok B TK Al-Fajar Pekanbaru ditemukan bahwa masih banyak anak yang belum mampu melakukan kegiatan melambungkan dan menangkap dengan berbagai media. Peneliti melihat kemampuan anak ternyata yang sudah mampu melambungkan dan menangkap bola hanya 3 anak (25\%) yang belum mampu 9 anak $(75 \%)$ hal ini terjadi karena guru kurang maksimal memberikan contoh kepada anak. Subyek penelitian adalah TK Al-Fajar Pekanbaru khususnya kelompok B yang berjumlah 12 orang anak, terdiri dari 6 anak perempuan dan 6 anak laki-laki, dengan usia anak 5-6 tahun. Waktu pelaksanaan direalisasikan selama 10 hari. Dalam kegiatan pertama masih banyak anak yang perlu bimbingan yaitu 10 anak $(83,3 \%)$ sedangkan anak yang sudah bisa melakukan kegiatan ada 2 anak (19,7 \%). dipertemuan kedua anak yang sudah bisa melakukan 4 anak (33\%), dan 8 anak (87\%) masih perlu bimbingan. Dipertemuan ketiga anak yang bisa bertambah menjadi 5 anak (42\%), anak yang masih memerlukan bimbingan 7 anak (58,3\%) . Pada pertemuan keempat, anak yang sudah bisa 8 anak (67\%), yang masih perlu bimbingan 4 anak (33\%). Pada pertemuan kelima anak yang sudah bisa bertambah 2 anak (16,7\%) anak yang sudah baik menjadi 10 anak $(83,3 \%)$ dan yang masih perlu bimbingan menjadi 2 anak (16,7\%). Pertemuan pertama pada siklus kedua anak melakukan kegiatan Melambungkan dan menangkap bola besar berhadapan, pada kegiatan ini anak yang sudah bisa melakukan 4 anak (33\%), yang masih perlu bimbingan 8 anak (67\%). Pada pertemuan kedua anak yang sudah bisa melakukan bertambah 2 anak sehingga jumlah anak yang sudah bisa menjadi 6 anak (50\%), dan yang memerlukan bimbingan 6 anak (60\%). Pada pertemuan ketiga anak yang bisa melakukan bertambah 1 sehingga jumlah anak yang bisa melakukan menjadi 7 anak (58,3\%), dan yang masih perlu bimbingan 5 anak (42\%). Pada pertemuan keempat anak yang bisa melakukan bertambah 3 anak jadi jumlah anak yang sudah sesuai harapan guru menjadi 9 anak (75\%), dan yang masih perlu bimbingan 3 anak (25\%). Pada pertemuan kelima anak melakukan kegiatan melambungkan dan menangkap bola sambil lari, pada kegiatan ini anak -anak sudah bisa melakukan kegiatan semua, dan anak yang memerlukan bimbingan sudah tidak ada lagi
\end{abstract}

Kata Kunci: Fisik, Motorik, Menangkap

\section{PENDAHULUAN}

\section{A. Latar Belakang}

Pendidikan Anak Usia Dini (PAUD)

adalah pendidikan yang ditunjukan untuk anak usia 0-6 tahun dibawah lembaga pendidikan. Paud ditujukan untuk anak Taman KanakKanak (TK), Kelompok Bermain (KB) Taman
Penitipan Anak (TPA). PAUD bertujuan untuk mengembangkan seluruh potensi sejak dini sehingga anak berkembang secara wajar.

Taman Kanak-Kanak merupakan satuan pendidikan formal pertama yang diselenggarakan dalam rangka mewujudkan tujuan pendidikan Nasional. 
Untuk itu TK sebagai lembaga pendidikan mempunyai tanggung jawab berperan serta mengembangkan potensi anak didik, supaya berkembang secara optimal baik sebagai individu maupun sebagai anggota masyarakat.

Taman Kanak-Kanak adalah salah satu lembaga pendidikan formal yang berusia 4-6 tahun. Dengan prinsip belajar sambil bermain, bermain seraya belajar. Pada pendidikan anak usia dini, dituntut guru yang propesional dalam mengajar. Guru yang propesional bukan saja dituntut dapat mengembangkan program pendidikan, tetapi juga dapat membuat inovasi-inovasi baru di lembaga tempatnya mengajar. Tuntutan ini berkembang seiring dengan perkembangannya pengetahuan dan kesadaran masarakat tentang pentingnya anak usia dini. Sikap kritis masyarakat diharapkan dapat mendorong lembaga-lembaga PAUD untuk maju dan selalu mengikuti perkembangan pengetahuan anak usia dini.

Untuk mengetahui berhasil tidaknya proses pembelajaran, salah satu cara adalah dengan melakukan observasi yang bertujuan untuk mengumpulkan data secara lengkap baik ketika merencanakan maupun ketika melaksanakan kegiatan pembelajaran termasuk memecah kan masalah yang ditemukan dalam kegiatan pembelajaran. Agar mampu melaksanakan kegiatan tersebut guru harus menguasai kompetensi keguruan yang mencakup penguasaan berbagai bidang pengembangan di Taman Kanak-Kanak. Salah satunya adalah penguasaan bidang pengembangan fisik motorik kasar.

Kegiatan pembelajaran sekolah dikatakan berhasil apabila pembelajaran yang disajikan guru dapat dikuasai oleh anak. Dan dikatakan belum berhasil apabila masih banyak anak yang belum menguasai materi pembelajaran. Namun kenyataannya peneliti temukan dikelompok B TK Al-Fajar Pekanbaru masih banyak anak yang belum mampu melakukan kegiatan melambungkan dan menangkap berbagai media. Peneliti melihat kemampuan anak yang berjumlah 12 anak. Ternyata yang sudah mampu melakukan melambungkan dan menangkap bola hanya 3 anak (25\%) yang belum mampu 9 anak (75\%) hal ini terjadi karena guru kurang maksimal memberikan contoh kepada anak.

Berdasarkan masalah tersebut penulis melakukan refleksi tentang apa yang telah dilakukan selama mengajar dan meminta teman sejawat untuk memberikan masukan dan konsultasi dengan supervisor, penulis mencoba melakukan perbaikan pembelajaran melalui penelitian tindakan kelas. Sehingga penulis memberikan judul Pemantapan Kemampuam Propesional (PKP) ini dengan judul: "Upaya Meningkatkan Kemampuan Motorik Kasar Anak melalui kegiatan melambungkan dan menangkap dengan berbagai media pada anak kelompok B TK Al-Fajar Pekanbaru.

\section{B. Rumusan masalah.}

Dari identifikasi masalah tersebut maka rumusan masalah penelitian ini adalah Bagaimana meningkatkan kemampuan motorik kasar anak melalui kegiatan melambungkan dan menangkap dengan berbagai media pada anak kelompok B TK AlFajar Pekanbaru?.

\section{Tujuan Penelitian}

Tujuan perbaikan bidang pengembangan ini secara umum adalah: untuk meningkatkan aktifitas anak dalam melakukan kegiatan melambungkan dan menangkap berbagai media (bola, kertas dan kantong biji).

\section{KAJIAN PUSTAKA}

\section{A. Pengertian Motorik Kasar}

Menurut Bambang Sujiono (2007) Motorik kasar adalah Semua gerakan yang dapat dilakukan oleh seluruh anggota tubuh 
yang disebut sebagai perkembangan dari unsur kematangan dan mengendalikan gerakan tubuh.

Kemampuan Motorik kasar anak usia dini 4-6 tahun mempunyai perbedaan dengan orang dewasa dalam hal berjalan, hanya mempergunakan otot-otot yang diperlukan saja sedangkan anak-anak berjalan seolaholah seluruh tubuhnya ikut bergerak -gerak. Dalam hal menyepak menendang bola diikuti dengan kedua belah tangannya yang turut maju ke depan secara berlebihan. Masa lima tahun pertama adalah masa emas bagi perkembangan motorik anak. Perkembangan keterampilan motorik merupakan faktor yang sangat penting bagi perkembangan kepribadian anak secara keseluruhan. Elizebeth Hurlock (1956)

Menurut Maxim (1993) menyatakan bahwa anak usia dini mempunyai kemampuan belajar dan rasa ingin tahu yang sangat tinggi. Pada usia ini anak mengalami perkembangan yang pesat dari semua aspek, baik kognitif, afektif maupun fisik. Anak usia Taman Kanak-Kanak pada umumnya sangat aktif, mereka memiliki penguasaan terhadap tubuhnya dan sangat menyukai kegiatan yang dilakukan sendiri. Oleh karna itu orang tua atau guru perlu menyediakan ruang dan waktu bagi anak untuk melakukan kegiatan yang dapat melatih otot kasar anak serta menyediakan barang-barang dan peralatan bagi anak yang bisa didorong, diangkat, dilempar atau dijinjing.

Anak usia dini adalah anak usia $0-8$ tahun, dimana pada usia ini anak mengalami lompatan perkembangan, kecepatan perkembangan yang luar biasa dibanding usia sesudahnya. Pada usia tersebut merupakan periode diletakannya dasar struktur kepribadian yang dibangun untuk sepanjang hidupnya. Perkembangan fisik dan mental pada usia 0-8 tahun mengalami kecepatan yang luar biasa. Perkembangan kemampuan fisik pada anak kecil bisa diidentifikasikan dalam beberapa hal. Sifat -sifat perkembangan fisik yang dapat diamati adalah sebagai berikut:

- Terjadi perkembangan otot-otot besar cukup cepat pada 2 tahun terakhir masa anak kecil. Hal ini memungkinkan anak melakukan berbagai gerakan yang lebih leluasa yang kemudian bisa dilakukannya bemacam-macam gerak dasar. Beberapa macam gerak dasar misalnya: berlari, melonjat, berjengket, melempar, menangkap, dan memukul secara bersamaan tetapi dengan irama perkembangan yang berlainan. Ada yang lebih cepat dikuasai dan ada yang dikuasai kemudian.

- Dengan berkembangnya otot-otot besar, terjadi pulalah perkembamgan kekuatan yang cukup cepat, baik pada anak laki-laki maupun perempuan. Antara usia 3 sampai 6 tahun terjadi peningkatan kekuatan sampai mencapai lebih kurang $65 \%$.

- Pertumbuhan kaki dan tangan secara propesional lebih cepat dibanding pertumbuhan bagian tubuh yang lain.

- Terjadi peningkatan koordinasi gerak dan keseimbangan tubuh yang cukup cepat. Koordinasi gerak yang meningkat dan disertai dengan daya ungkit kaki dan tangan yang makin besar, menjadikan anak makin mampu menggunakan kekutannya didalam melakukan aktifitas fisik.

- Meningkatnya kemungkinan dan kesempatan melakukan berbagai macam aktifitas gerak fisik bisa merangsang perkembangan pengenalan konsep-konsep dasar objek, ruang gaya, waktu dan sebab akibat. Melalui gerakan fisik anak kecil mulai mengenali konsep dasar objek yang berada di luar dirinya. 


\section{B. Melambungkan dan menangkap}

Melambung dan Menangkap adalah keterampilan gerak dasar manipulasi yang melibatkan penghentian momentum suatu benda serta mengendalikan dengan kedua tangan. Pada dasarnya untuk gerakan menangkap dikarakteristikkan dengan menggunakan cara menempatkan tangan pada posisi efektif saat menerima benda melayang, dipegang dengan kedua tangan serta menunjukan pengendalian objek yang di maksud. Menurrut Http: / Darunnajah Kindergarten. Com/2011.

Selain menggunakan bola,
melambungkan dan menangkap dapat menggunakan kantong biji, kegiatan tersebut adalah salah satu pengembangan fisik /motorik di Taman Kanak-kanak. Pengembangan fisik /motorik merupakan salah satu pengembangan kemampuan dasar di Taman Kanak-kanak. Bahan kegiatan lainnya mencakup kegiatan yang mengarah pada kegiatan untuk melatih motorik kasar dan halus yang terdiri dari gerak-gerak jalan, lari, lompat, senam, menari, memanjat, berjalan dititian, berayun,merangkak, merayap dll.

Fungsi dari kegiatan fisik/motorik tersebut adalah

- Melatih kelenturan dan koordinasi otot jari dan tangan.

- Memacu pertumbuhan dan pengembangan fisik/motorik, rohani, dan kesehatan anak.

- Membentuk, membangun, dan memperkuat tubuh anak.

- Melatih keterampilan gerak dan berfikir anak.

- Melatih perkembangan emosional dan social anak.

- Menumbuhkan perasaan senang kepada anak.

Menurut Irwansyah Asep Kurnia Nenggala (2004) Cara Melambungkan dan
Menangkap Bola diantaranya adalah sebagai berikut:

- Lempar dan tangkap bola perorangan. Berdiri tegak dengan mmemegang bola. Kemudian berjalan sambil melempar dan menangkap bola.

- Lempar dan Tangkap bola perpasangan. Berdirilah berhadapan dan berpasangan dengan temanmu.

- Lakukan lempar dan tangkap bola dengan teman

\section{MEDIA}

Menurut Heinich, Molenda dan Russel(1993) Dalam Badru Zaman, Asep Heri Hernawan, cucu eliayawati, (2009).Media berarti 'perantara' yaitu perantara sumber sumber pesan dengan penerima pesan. Media pembelajaran juga mampu memberikan kontribusi yang sangat besar terhadap tercapainya kemampuan-kemampuan belajar anak TK yang diharapkan. Pemanfaatan media pembelajaran di TK, diantaranya adalah:

- Penggunaan media pembelajaran bukan merupakan fungsi tambahan, tetapi memiliki fungsi tersendiri sebagai sarana bantu untuk mewujudkan situasi pembelajaran yang lebih efektif.

- Media pembelajaran merupakan bagian integral dari keseluruhan proses pembelajaran. Hal ini mengandung pengertian bahwa media pembelajaran sebagai salah satu komponen yang tidak berdiri sendiri tetapi saling berhubungan dengan komponen lainnya dalam rangka menciptakan situasi belajar yang diharapkan.

- Media pembelajaran dalam penggunaannya harus relevan dengan tujuan dan isi pembelajaran. Hal ini mengandung makna bahwa penggunaan media dalam pembelajaran harus selalu melihat kepada 
tujuan atau kemampuan yang akan dikuasai anak dan bahan ajar.

Sementara itu, Briggs (1077) berpendapat bahwa media pembelajaran adalah sarana fisik untuk menyampaikan isi/materi pembelajaran: buku, film, vidio dan sebagainya. Sedangkan, National Education Associaton (1969) mengungkapkan bahwa media pembelajaran adalah sarana komunikasi dalam bentuk cetak maupun pandang-dengar, termasuk teknologi perangkat keras. Dari pendapat tersebut disimpulkan bahwa media pembelajaran adalah segala sesuatu yang dapat menyalurkan pesan, dapat merangsang fikiran, perasaan, dan kemauan peserta didik sehinggandapat mendorong terciptanya proses belajar pada diri peserta didik. Media memiliki beberapa pungsi, diantaranya adalah:

- Media pembelajaran dapat mengatasi keterbatasan pengalaman yang dimiliki oleh peserta didik.

- Media pembelajaran dapat melampaui batasan ruang kelas.

- Media pembelajaran memungkinkan adanya interaksi langsung antara peserta didik dengan lingkungannya.

- Media menghasilkan keseragaman pengamatan

- Media dapat menanamkan konseop dasar yang benar, konkrit, dan realistis.

- Media membangkitkan keinginan dan minat baru.

- Media membangkitkan motifasi dan merangsang anak untuk belajar.

- Media memberikan pengalaman yang integral/menyeluruh dari yang kongkrit sampai dengan abstrak. Dalam http:/Jonainf semua. Blogsspot. Com/2011/01/media.

PELAKSANAAN PERBAIKAN

A. Subyek Penelitian
Subyek penelitian adalah TK Al-Fajar Pekanbaru khususnya kelompok B yang berjumlah 12 orang anak, terdiri dari 6 anak perempuan dan 6 anak laki-laki, dengan usia anak 5-6 tahun. Waktu pelaksanaan direalisasikan selama 10 hari. Guru sebagai pendidik berperan sebagai peneliti dan pelaksanaan perbaikan harus memiliki rencana jangka panjang dalam bentuk rencana kegiatan, strategi pembelajaran dan pelaksanaan perbaikan

Untuk memenuhi kebutuhan belajar anak usia 5-6 tahun yang memiliki karakter unik, dalam merencanakan/melaksanakan kegiatan pengembangan harus memperhatikan berbagai karakter yang ada pada diri anak, khususnya anak TK. Berbeda dengan fase usia anak lainnya, untuk anak usia dini memiliki karakteristik yang khas. Beberapa karakteristik anak usia dini antara lain adalah Memiliki rasa ingin tahu yang besar, merupakan pribadi yang unik, suka berfantasi dan berimajinasi. Dengan berbagai karakteristik yang ada pada diri anak usia dini tersebut, guru dituntut untuk aktif, kreatif dan inovaif serta memberikan kegiatan yang menantang bagi anak. Kegiatan perbaikan disetiap siklus dilaksanakan sesuai dengan jadwal yang ditentukan.

\section{B. Deskripsi Perencanaan dan Pelaksanaan 1. Rencana}

Anak sebagai peserta didik merupakan subyek utama dalam proses pembelajaran. Keberhasilan dalam mencapai tujuan pembelajaran banyak, ditentukan pada kesiapan dan cara belajar yang dilakukan anak. Disamping itu guru juga sangat berperan penting, guru dituntut harus menguasai apa yang akan diajarkan melalui aktifitas dengan berbagai metode dan media yang sesuai dengan tingkat perkembangan anak.

Guru harus peka terhadap permasalahan yang muncul dalam proses 
Upaya Meningkatkan Kemampuan Fisik Motorik Kasar Anak Melalui Kegiatan Melambungkan dan Menangkap dengan Berbagai Media Anak Usia Dini Di TK Al- Fajar Pekanbaru

pembelajaran yang kemudian menindak lanjuti dalam tindakan perbaikan. Dalam pengamatan kegiatan pengembangan terdapat beberapa kelemahan antara lain adalah: Kurangnya minat anak dalam melakukan kegiatan pengembangan Fisik Motorik Kasar, melalui kegiatan melambungkan dan menangkap berbagai media. Kelemahan tersebut akan ditindak lanjuti dalam perbaikan pembelajaran melalui Penelitian Tindakan Kelas (PTK). Langkah awal dalam melakukan kegiatan perbaikan adalah membuat rencana perbaikan yang dilaksanakan dalam dua siklus sebagai berikut:

1) Pelaksanaan siklus I dengan tema "Tanah Air". Langkah yang harus dilakukan guru adalah membuat rencana kegiatan untuk satu siklus (selama 5 hari) yang erdiri dari:

- Rancangan satu siklus

- Rencana kegiatan untuk lima hari kegiatan

- RKH (Rencana Kegiatan Harian) selama satu siklus

- Skenario Perbaikan

- Refleksi.

2) Pelaksanaan siklus II dengan tema "Tanah Air" dengan rencana sebagai berikut:

- Rancangan satu siklus.

- Rencana Kegiatan untuk lima hari kegiatan.

- Rencana Kegiatan Harian (RKH) selama satu siklus.

- Skenario Perbaikan

3) Refleksi. Kemudian melakukan tindakan perbaikan kegiatan pengembangan sesuai dengan rencana yang telah disusun secara sistematis dan tematik.

\section{Pelaksanaan}

Untuk mendapatkan data yang akurat dalam mengamati kegiatan perbaikan kegiatan pengembangan, guru sebagai peneliti, pengamat sekaligus pelaksana perbaikan, dibantu oleh pengamat 1 dan pengamat 2 yaitu teman sejawat dan supervisor.

Pelaksanaan perbaikan dilaksanakan dengan langkah-langkah sebagai berikut:

\section{Perbaikan pembelajaran siklus I.}

a) Melakukan kegiatan awal. Apersepsi guru mengingat pelajaran yang lalu dan mengarahkan kepada materi yang akan diajarkan pada hari ini yaitu pengembangan fisik motorik kasar melalui kegiatan melambungkan dan menangkap berbagai media (bola). Sebelum masuk inti anakanak di ajak melakukan pemanasan terlebih dahulu.

b) Melakukan kegiatan inti guru mendemostrasikan kegiatan yang akan dilakukan pada hari ini dengan menggunakan media bola, selanjutnya guru meminta anak-anak untuk mencoba satu persatu, kemudian melakukan penilaian untuk mengetahui perkembangan anak.

c) Melakukan kegiatan akhir anak-anak diajak melakukan pendinginan, guru menyimpulkan hasil perbaikan yang telah dilakukan bertujuan melihat permasalahan / hal-hal yang munculuntuk ditindak lanjuti dalam kegiatan perbaikan.

\section{Perbaikan pembelajaran siklus II.}

Dalam proses kegiatan perbaikan siklus II kegiatan pengembangan guru menyiapkan langkah -langkah umum prosedur pembelajaran sebagai berikut:

a) Melakukan kegiatan awal. Apresiasi yaitu guru mengingatkan pelajaran yang lalu dan mengarahkan kegiatan hari ini yaitu kegiatan pengembangan fisik motorik kasar yang akan dilaksanakan kegiatan melambungkan dan menangkap dengan berbagai media (kantong biji). Sebelum menginjak inti anak-anak di ajak pemanasan terlebih dahulu. 
b) Melakukan kegiatan inti dengan memberikan contoh kepada anak sesuai dengan kegiatan perbaikan kegiatan pengembangan dengan menggunakan media bola, anak-anak diberi tugas untuk melakukan kegiatan satu persatu kemudian mengadakan penilaian yang telah dilakukan, untuk mengetahui keberhasilan dan perkembangan anak.

c) Melakukan kegiatan akhir dengan menyimpulkan hasil kegiatan perbaikan, selanjutnya anak-anak diajak pendinginan, pengembangan yang telah dilakukan bertujuan melihat permasalahan / hal-hal yang muncul untuk tindak lanjut dalam kegiatan perbaikan.

\section{Pengamatan}

Instrumen yang digunakan dan data yang dikumpulkan didapat dari penilaian hasil belajar pada saat melakukan perbaikan pembelajaran data yang dikumpul terdiri dari data pada siklus I dan data siklus II. Pengamatan oleh guru dan dibantu teman sejawat dengan menggunakan lembar observasi.

\section{Refleksi}

Kegiatan refleksi dilakukan setelah melakukan perbaikan kegiatan pembelajaran disetiap siklus yang dilaksanakan. Data yang diperoleh berasal dari hasil observasi penilaian anak. Refleksi dilakukan bersama dengan supervisor 2 untuk melakukan analisis tentang kekurangan dan kelebihan dari metode dan media yang digunakan .kekuatan dan kelemahan peneliti temui dalam melaksanakan perbaikan perbaikan pembelajaran adalah, kurangnya pendidik memotivasi anak dalam kegiatan yang sedang berlangsung. Keuatan yang penliti rasakan dengan metode peneliti gunakan sudah sesuai dengan tingkat kembangan anak, media yang bervariasi sudah tepat dalam melakukan kegiatan perbaikan pembelajaran.

\section{HASIL PENELITIAN DAN PEMBAHASAN}

Hasil penelitian terhadap kegiatan perbaikan kegiatan pengembangan yang bertujuan untuk meningkatkan minat anak TK Al-Fajar Pekanbaru dalam pengembangan fisik motorik kasar melalui kegiatan "Melambungkan dan menangkap dengan berbagai media" telah diadakan tindakan perbaikan yang dilaksanakan melalui dua siklus. Hasil dan pembahasan kegiatan perbaikan yang telah dilaksanakan setiap siklusnya akan dideskripsikan sebagai berikut:

\section{A. Deskripsi Persiklus}

Berdasarkan pengolahan data hasil pembelajaran kegiatan perbaikan kegiatan pengembangan terdapat kesimpulan hasil penilaian dalam bentuk grafik sebagai berikut:

\section{GRAFIK SIKLUS I}

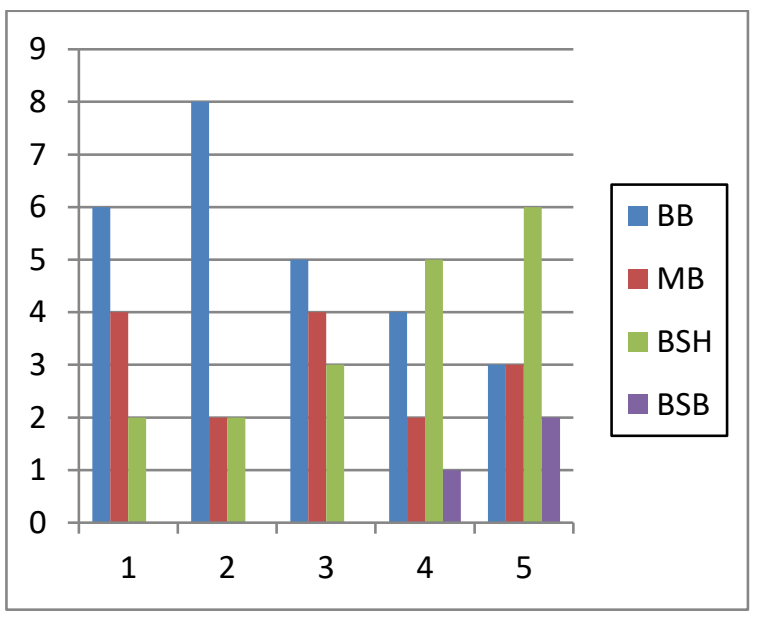

Dari data pada tabel 5 di atas, terlihat ada peningkatan hasil perolehan nilai anak dalam melaksanakan kegiata melambungkan dan menangkap dengan berbagai media, terlihat pada siklus I memperoleh hasil/nilai BSH $50 \%$ yaitu yaitu hanya 6 anak, dan yang masih perlu bimbingan 6 anak (50\%). Dalam 
kegiatan perbaikan pembelajaran melalui kegiata dengan menggunakan media yang berbeda-beda terlihat adanya peningkatan, dibandingkan data awal yang memperoleh nilai MB 2 anak (16,7\%), yang perlu bimbingan 10 anak $(83,3 \%)$

\section{Grafik Siklus II}

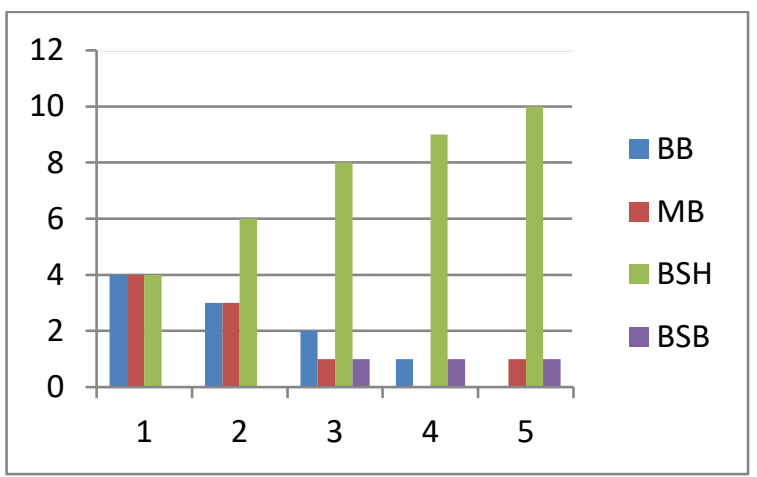

Dari grafik diatas, dapat dilihat nilai ketuntasan minimal BSH dengan kategori berkembang sesuai harapan. Pada siklus ke II terlihat banyak kenaikan yang mendapat nilai BSH mencapai 10 anak $(83,3 \%)$, kemudian yang mendapat nilai di atas BSH yaitu BSB 1 anak $(8,3 \%)$, dan yang mendapat nilai MB1 anak $(8,3 \%)$. Dan sudah tidak ada anak yang perlu bimbingan, jadi semua anak sudah bisa melakukan kegiatan melambungkan dan menangkap dengan berbagai media

Sesuai dengan tujuan perbaikan yang telah dilaksanakan dari siklus I dan siklus II yaitu meningkatkan perkembangan kemampuan fisik motorik kasar anak melalui kegiatan, Melambungkan dan menangkap dengan berbagai media. Hasil pelaksanaan perbaikan pembelajaran kegiatan pengembangan untuk siklus I, sebagai berikut:

- Dalam skenario perbaikan pada pertemuan pertama, kegiatan yang dilakukan adalah melambungkan dan menangkap bola besar diam di tempat, anak dibawa kehalaman sekolah kemudian membuat lingkaran untuk melakukan pemanasan. Pada RKH pertama ini anak melakukan gerakan melambungkan dan menangkap diam di tempat dengan media bola. Pada kegiatan ini banyak anak yang enggan melakukan, sehingga banyak yang perlu bimbingan.

- Sekenario perbaikan pembelajaran kedua kegiatan yang dilakukan adalah melambunkan dan menangkap bola kertas. Anak dibawa ke aula untuk membuat barisan dan melakukan pemanasan dengan jalan ditempat. Kemudian guru mencontohkan cara melambungka bola kertas yang benar, sebagian anak ada yang sudah bisa melakukan sebagian lagi ada yang belum bisa melakukan namun aktifitas anak masih perlu ditingkatkan.

- Skenario pertemuan ketiga kegiatan yang dilakukan adalah melambungkan dan menangkap kantong biji, anak diajak ke aula kemudian membentuk lingkaran dan melakukan pemanasan pada RKH ini anak melakukan kegiatan melambungkan kantong biji. Guru memberi contoh cara melambungkan kantong biji yang benar, anak mulai termotivasi. Ada beberapa anak yang masih kesulitan dalam melakukan ini guru terus membimbing anak yang masih tampak kesulitan

- Skenario perbaikan pembelajaran keempat kegiatan yang dilakukan adalah meningkatkan kemampuan anak dalam melakukan kegiatan melambungkan dan menangkap bola kecil (bola kasti). Anak diajak ke aula kemudian melakukan pemanasan. Guru memberi contoh cara melambungkan bola kecil dalam kegiatan ini ada yang masih belum bisa melakukan tinggal beberapa orang, guru terus membimbing dan memotivasi anak.

- Skenario perbaikan pembelajaran kelima kegiatan yang dilakukan adalah melambungkan dan menangkap bola sedang sambil jalan, anak diajak ke aula membentuk lingkaran untuk melakukan pemanasan guru mencontohkan kegiatan 
melambungkan dan menangkap bola sedang sambil jalan. Pada kegiatan ini tidak ada anak yang bermain-main lagi.

- Pada akhir kegiatan perbaikan pembelajaran siklus I ini terlihat anak antusias dalam melakukan melambungkan dan menangkap dengan berbagai media.

$$
\text { Hasil perbaikan kegiatan }
$$

pengembangan untuk siklus ke II dengan tema Tanah Air rencana perbaikannya sebagai berikut:

- Pertemuan pertama pada siklus kedua dalam sekenario perbaikan pembelajaran, tujuan perbaikan pembelajaran adalah meningkatkan kemampuan melambungkan dan menangkap dengan berbagai media . Pada RKH ini tertulis kegiatan yang akan di lakukan melambungkan dan menangkap bola sambil berhadapan, anak dibawa keluar kelas untuk membentuk dua barisan berhadapan dan melakukan pemanasan guru mencontohkan cara melambungkan bola berhadapan dengan teman, dalam kegiatan ini masih ada anak yang perlu bimbingan.

- Pertemuan kedua pada skenario perbaikan pembelajaran tertulis tujuan perbaikan adalah meningkatkan kemampun dalam melambungkan dan menangkap berbagai media. Pada RKH ini anak diajak melakukan kegiatan melambungkan dan menangkap bola kertas berhadapan, anak dibawa ke halaman membentuk dua barisan dan melakukan pemanasan, guru mencontohkan kegiatan yang akan dilakukan anak-anak merasa gembira dan senang.

- Pada pertemuan ketiga skenario perbaikan pembelajaran kegiatan yang dilakukan adalah melambungkan dan menangkap kantong biji sambil memutar badan, anak dibawa ke aula membentuk lingkara kemudian anak melakukan pemanasan. Guru mendemostrasikan kegiatan tersebut lalu guru memberi semangat dan dukungan kepada anak agar anak melakukan kegiatan dengan semangat dan gembira.

- Pertemuan keempat pada skenario perbaikan pembelajaran kegiatan yang dilakukan adalah melambungkan dengan satu tangan ditangkap dengan dua tangan menggunakan medi bola kecil (bola Kasti). Anak dibawa keluar kelas ke aula membentuk lingkaran lalu melakukan pemanasan, guru mencontohkan kegiatan tersebut kemudian anak-anak mencoba satu persatu, dalam kegiatan ini banyak anak yang sudah bisa hanya satu anak yang masih perlu bimbingan.

- Pada pertemuan kelima skenario perbaikan pembelajaran kegiatan pembelajaran yang dilakukan melambungkan dan menangkap bola sedang sambil lari. Pada RKH ini guru membawa anak ke aula dan melakukan pemanasan, guru mendemostrasikan gerakan yang akan dilakukan kemudian anak menirikan kegiaan tersebut, pada kegiatan ini semua anak terlihat gembira dan melakukan kegiatan dengan senang.

- Pada akhir kegiatan perbaikan pembelajaran disiklus II ini terlihat anak antusias dalam melakukan kegiatan melambungkan dan menangkap dengan berbagai media, hal ini terjadi seringnya guru memotivasi anak dalam melakukan kegiatan

\section{B. Pembahasan Dari Setiap Siklus}

Pada pertemuan pertama siklus ke I dengan kegiatan melambungkan dan menangkap bola besar diam di tempat, anak yang melakukan kegiatan 12 anak. Dalam kegiatan pertama masih banyak anak yang perlu bimbingan yaitu 10 anak $(83,3 \%)$ 
sedangkan anak yang sudah bisa melakukan kegiatan ada 2 anak $(19,7 \%)$. dipertemuan kedua kegiatan perbaikan pembelajaran kegiatan yang dilakukan anak melambungkan dan menangkap bola kertas. Dikegiatan ini anak yang sudah bisa melakukan 4 anak (33\%), dan 8 anak (87\%) masih perlu bimbingan. Dipertemuan ketiga kegiatan perbaikan pembelajaran melakukan melambungkan dan menangkap kantong biji, dikegiatan ini anak yang bisa bertambah 1 anak semua menjadi 5 anak (42\%), anak yang masih memerlukan bimbingan 7 anak (58,3\%) . Pada pertemuan keempat kegiatan perbaikan pembelajaran anak melakukan melambungkan dan menangkap bola kecil (bola kasti), pada kegian ini anak yang sudah bisa melakukan 3 anak (25\%), anak yang sudah bisa 8 anak (67\%), yang masih perlu bimbingan 4 anak (33\%). Pada pertemuan kelima kegiatan yang dilakukan Melambungkan dan menangkap bola sedang sambil lari. Dipertemuan kelima ini anak yang sudah bisa bertanbah 2 anak $(16,7 \%)$ anak yang sudah baik menjadi 10 anak $(83,3 \%)$ dan yang masih perlu bimbingan menjadi 2 anak (16,7\%).

Pertemuan pertama pada siklus kedua ini anak melakukan kegiatan Melambungkan dan menangkap bola besar berhadapan, pada gegiatan ini anak yang sudah bisa melakukan 4 anak (33\%), yang masih perlu bimbingan 8 anak (67\%). Pada pertemuan kedua dengan kegiatan Melambungkan dan menangkap bola kertas sambil berhadapan, pada kegiatan ini anak yang sudah bisa melakukan bertambah 2 anak sehingga jumlah anak yang sudah bisa menjadi 6 anak (50\%), dan yang memerlukan bimbingan 6 anak (60\%). Pada pertemuan ketiga anak melakukan kegiatan Melambungkan dan menangkap kantong biji sambil memutar badan, pada kegiatan ini anak yang bisa melakukan bertambah 1 sehingga jumlah anak yang bisa melakukan menjadi 7 anak (58,3\%), dan yang masih perlu bimbingan 5 anak (42\%). Pada pertemuan keempat anak melakukan kegiatan melambungkan bola kecil dengan satu tangan dan ditangkap dengan dua tangan. pada kegiatan ini anak yang bisa melakukan bertambah 3 anak jadi jumlah anak yang sudah sesuai harapan guru menjadi 9 anak (75\%), dan yang masih perlu bimbingan 3 anak $(25 \%)$. Pada pertemuan kelima anak melakukan kegiatan melambungkan dan menangkap bola sambil lari, pada kegiatan ini anak -anak sudah bisa melakukan kegiatan semua, dan anak yang memerlukan bimbingan sudah tidak ada.

Proses pelaksanaan perbaikan siklus I dan siklus II dengan kegitan melambungkan dan menangkap dengan berbagai media dan berbagai metoda, yang dilaksanakan dikegiatan awal dari jam 08.00-08.20 WIB selama 10 hari pertemuan. Bahwa harapan sudah tercapai salah satu teori yang mendukung Heinich, Molenda dan Russel (1993) Dalam Badru Zaman, Asep Heri Hernawan, $\mathrm{Cucu}$ Eliayawati adalah dengan berbagai media yang berfariasi anak dapat melakukan kegiatan dengan semangat dan gembira.

\section{KESIMPULAN DAN SARAN}

\section{A. Kesimpulan}

Dari hasil perbaikan pembelajaran yang telah dilaksanakan dapat ditarik beberapa kesimpulan sebagai berikut:

1) Penggunaan medi untuk meningkatkan pembelajaran fisik motorik kasar dapat meningkat di lihat dari perolehan nilai prasiklus, siklus I dan siklus II b. Efektifitas pembelajaran dapat ditingkatkan dengan bervariasi guru mengatur kegiatan pembelajaran.

2) Suasana belajar anak semakin terarah dan aktif. 


\section{B. Saran}

Berdasarkan dari kesimpulan yang dibuat, ada beberapa hal yang penulis sampaikan kepada rekan guru untuk meningkatkan kualitas pembelajaran untuk mencapai tujuan yang diharapkan antara lain:

1) Guru haruslah melaksanakan kegiatankegiatan yang dapat meningkatkan proses pembelajaran.

2) Sebelum mengajar guru diharapkan menguasai media dan metode pembelajaranr yang sesuai dengan kemampuan motorik kasar anak

3) Media dan metode pembelajaran dipersiapkan guru dengan sebaik-baiknya supaya pembelajaran dapat terlaksana sebagaimana yang diharapkan.

4) Menggunakan media yang bervarisi dan menarik.

5) Agar dapat menjadi masukan dalam membina guru menciptakan pembelajaran yang aktif, sehingga dapat meningkatkan hasil belajar anak.

6) Bagi peneliti diharapkan agar dapat melanjutkan penelitian yang sama dan lebih mendalami lagi untuk pengembangan ilmu pengetahuan.

\section{DARTAR PUSTAKA}

Andayani (2007). Pemantapan Kemampuan Propesional. Jakarta: Universitas Terbuka

Bambang Sujiono, dkk (2007) Metode

Pengembangan Fisik Jakarta:

Universitas Terbuka.

Edi Sih Mitranto, Slamet, (2010) Pendidikan Jasmani Olahraga dan Kesehatan Jakarta Pusat Perbukuan

Http:/Darunnajah Kindegarten. Com (2011). Online 2 Maret 2012-04-04

Http:/Jonainf Semua, Blogsspot. Com/2011/01/ Media berasal dari bahasa latin. Html online 10 Maret 2012.

Irwansyah Asep Kurnia Nenggala, (2004)

Sehat dan Tngkas Berolahraga

Bandung

Maxim George W (1993) The Very Young. Guiding Children from infancy The Through The Early Year.4 th Edition.New York: Mac Millon publishing company

Nar Herrhyanto, H.M. Akib Hamid. (2008). Statistika Dasar, Jakarta: Universitas Terbuka

Wardani,I.G.A.K, Wihardit K \& Nasution N (2006) Penelitian Tindakan Kelas. Jakarta: Universitas Terbuka 